Article

\title{
Between Rationalization and Political Project: The Existenzminimum from Klein and Teige to Today
}

\author{
Marson Korbi ${ }^{1}$ and Andrea Migotto ${ }^{2, *}$ \\ ${ }^{1}$ Department ICAR, Polytechnic of Bari, 70125 Bari, Italy; E-Mail: marson.korbi@poliba.it \\ 2 Faculty of Architecture, KU Leuven, 1030 Brussels, Belgium; E-Mail: andrea.migotto@kuleuven.be \\ * Corresponding author
}

Submitted: 29 March 2019 | Accepted: 21 June 2019 | Published: 30 September 2019

\begin{abstract}
A critical reflection on the II CIAM (Congrès Internationaux d'Architecture Moderne; in Frankfurt, 1929) should not limit itself to a purely historiographic reconstruction. The article discusses the II CIAM reflection on the Wohnung für das Existenzminimum (dwelling for the minimum level of existence) by means of a comparison between the official positions of participants and those of two architects, Alexander Klein and Karel Teige, who gravitated around the Frankfurt and Brussels meetings. The confrontation will unlock a double scenario. On the one hand, it will depict a multifaceted and more precise account of the discussion developed in the late 1920s on the minimum dwelling, integrating CIAM discussions with alternative theories and methods developed to face housing shortage and degraded living conditions. Investigating the impact of socio-economic conditions on household forms of life, Klein and Teige presented two paradigmatic and autonomous approaches that tackled the traditional solutions of architecture for the Existenzminimum. On the other hand, we argue that a broadened revision of the themes discussed at the end of the 1920s, namely the transformation of household compositions, the criticism of the paradigms of liberal urban development, the relation between production and forms of life as well as the position of the architect in housing production, proves to be useful for the understanding and overcoming of the fragmentation that still nowadays characterizes the reflection on domestic space.
\end{abstract}

\section{Keywords}

Alexander Klein; CIAM; collective dwelling; domestic space; housing crisis; Karel Teige; minimum dwelling; rationalization; Taylorism; universal dwelling

Issue

This article is part of the issue "Housing Builds Cities", edited by Luca Ortelli (École Polytechnique Fédérale de Lausanne, Switzerland), Chiara Monterumisi (École Polytechnique Fédérale de Lausanne, Switzerland) and Alessandro Porotto (École Polytechnique Fédérale de Lausanne, Switzerland).

(C) 2019 by the authors; licensee Cogitatio (Lisbon, Portugal). This article is licensed under a Creative Commons Attribution 4.0 International License (CC BY).

\section{Introduction: Modus Vivendi and the Return of the Minimum Dwelling}

At the 2008 Venice Biennale, while analyzing the situation of the residential market in Italy, Giovanni Caudo and Sofia Sebastianelli explained how the "retire of the public" within the Italian welfare scenario generated a housing shortage caused by an increasing reliance of housing provision on private sector and on market oscillations of supply and demand (Caudo \& Sebastianelli, 2009, pp. 40-47). Referring to a consolidated welfare cul- ture, what has entered into crisis, from around 2008, is the combination of financial and spatial frameworks that characterized familiar private domesticity and the traditional forms of welfare during the second half of 20th century (Allan \& Crow, 1989; Roland, 2008). According to Caudo and Sebastianelli, the lack of housing affordability was strongly related to "commodification" and "securitization", the latter defined as a process that channels housing debt on families' income (Bellicini, 2009).

Seen in perspective and considering the economic reassessment after the 2008 crisis (Madden \& Marcuse, 
2016, pp. 15-52), the reflection tackled in the Italian pavilion at the Venice Biennale can be taken as an initial point regarding the return of the housing question within the architectural debate. The trend has manifested itself in an increasing number of events and publications, amongst which the Wohnungsfrage exhibition at the HKW, in 2015 Berlin, the British Pavilion "Home Economics" at the 2016 Venice Architectural Biennale, the attempt to reframe the relation between private and collective within housing in the "Together! The New Architecture of the Collective" exhibition in 2017-or research on the domestic realm presented at the Chicago Architectural Biennale in 2017, which has characterized the reflection on housing from within the architectural field of inquiry. The renewed interest in the domestic sphere depends on its potential to effectively render the socio-economic transformation of our time and the crisis of the cultural constructions that have guided Western civilization since the introduction of welfare state measures in the second half of 20th century. While postwar housing socio-economic structures were based on a predefined household form (the family), legal regimes to establish the house as an "asset" through "property", be it ownership or rent (De Decker \& Dewilde, 2010; Doling \& Elsinga, 2013), and socially structured typologies (family home and apartment), in the last decades, the transformations of capitalist accumulation, paralleled by the shrinking possibilities of the public sector, have drastically impacted the sphere of dwelling and its architecture.

To reassess the qualities of domestic space in light of current transformations, we argue that it is necessary to look at the parallel evolution of subjects, weather workers, citizens or households, and to highlight their rela- tion to the space they inhabit. In 2007, the Italian intellectual Sergio Bologna highlighted how the crisis of the middle class of the last decade coincides with the rise of knowledge workers (freelance, part-time workers, etc.), defined as a new generic proletariat (Bologna, 2007). Precarious, autonomous, and flexible labor are forms of working contracts where work, by occupying the entirety of existence and life, determines the modus vivendi within the city. This shift parallels the crisis of the traditional household, of the modern culture of domesticity, and of the separation between the productive and reproductive spheres (Ariès, 1996; Heynen, 2005; Heynen \& Baydar, 2005).

In this article, we argue that the spreading condition of minimum dwelling, both as a living space and as a life condition, is a tendency that makes tangible these social and political shifts typical of our age. In our understanding, the minimum dwelling is a living space characterized by the extreme reduction of inhabitable surface (see Figure 1) as a consequence of private market speculation. To discuss the difference between minimum dwelling as a living condition and the Existenzminimum as an architectural project, we look at the 1929 II CIAM (Congrès Internationaux d'Architecture Moderne), the first moment where the features of domestic life were tackled as concrete givens to establish a new social project and an operative agenda for modern architecture.

\section{Establishing the Existenzminimum Project: The CIAM Debate}

For architects, after the WWI, the housing question did not simply entail a quantitative shortcoming, but a deeper theoretical problem on the structural rationale
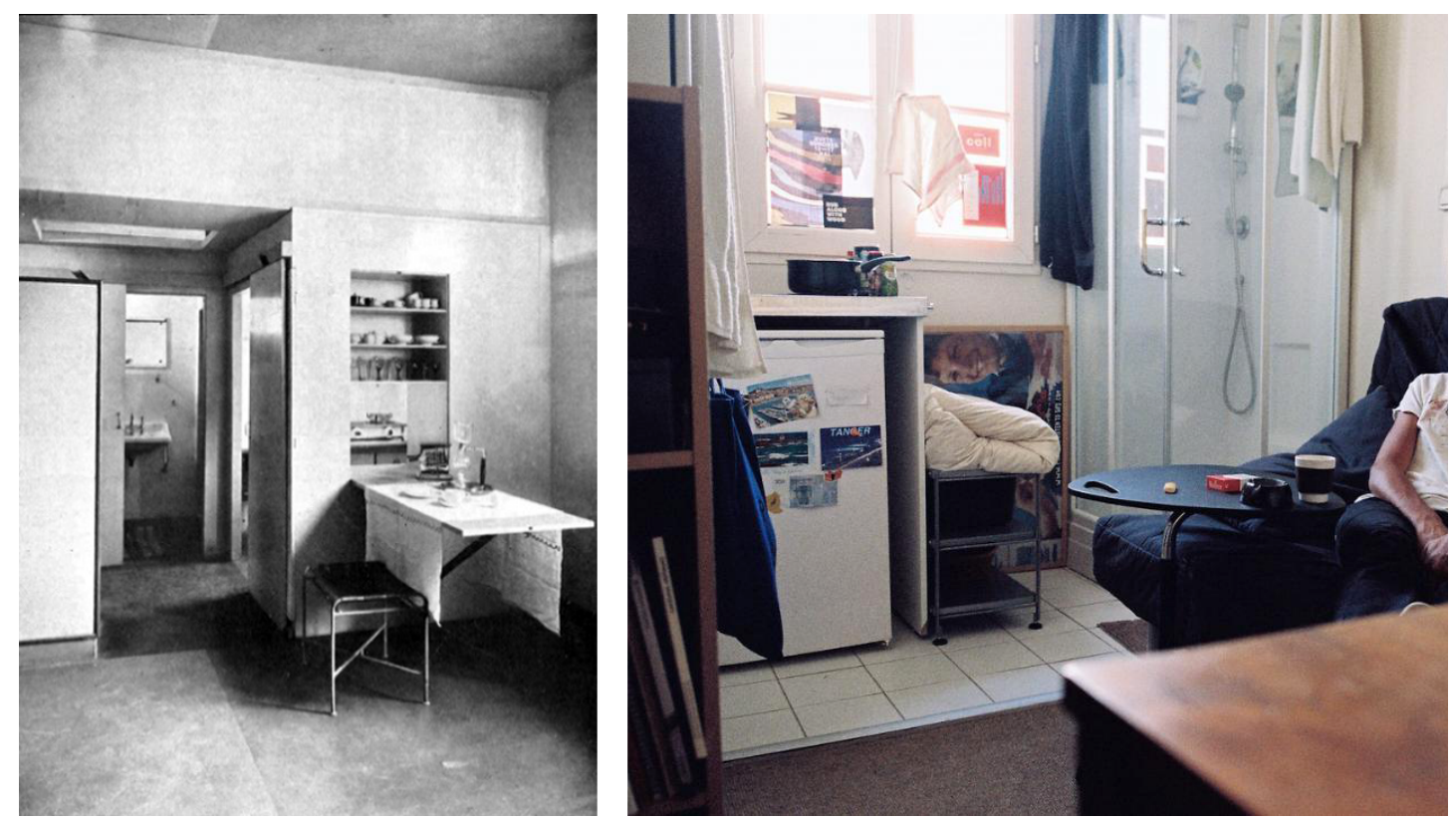

Figure 1. Minimum dwellings from II CIAM to today. From left to right: View of a bachelor room (Junggesellenzimmer), architect Kienzle (Giedion, 1929); Parisian micro-flat (Ghislain, student, in his fifth floor $10 \mathrm{~m}^{2}$ apartment; Macherez, 2015). 
of dwelling production, distribution, and use. Engels' famous position regarding the "housing question" proved to be impracticable (Engels, 1872). As Aymonino commented, the perspective of a proletarian revolution slowly disappeared from the agenda with the rise of reformist instances, in an attempt to transform capitalism from within (Aymonino, 1971). Defining new architectural qualities for the living space was crucial. The Wohnung für das Existenzminimum (dwelling for the minimum level of existence) was chosen as the topic for the 1929 II CIAM, in Frankfurt, in order to put the rising modern attitude in architecture at the center of the socioeconomic discussion, especially regarding the problem of the living-unit for the lower classes (Grassi, 1975). At the same time, by directly engaging in such an issue, organizers aimed to establish a clear agenda for the CIAM and establish the organization as a new compact organism able to internationally promote modern architecture (Gubler, 2012, pp. 231-255; Mumford, 2000, pp. 27-44).

The Existenzminimum worked as a theoretical manifesto to guide modern architects' reflection on the production of affordable living-units for the working classes. The recurrent worry in the 1920s was the reduction of dwellings surface and the degenerative living conditions that characterized working-class housing in the metropolis of industrial capitalism. CIAM relators targeted the plethora of speculative, philanthropic and even utopiansocialist projects that characterized housing production in the second half of the Nineteenth century (Bullock \& Read, 2011; Guerrand, 1981). On the other hand, the modern paradigm was built upon the socio-political concern of granting workers a space to fulfill their biological needs: the "minimum" was defined as a liminal condition, a space not-appropriable by market law practices (Thomas, 2015). The process would not be painless. It demanded new actors and stakeholders to enter the productive arena and to question the dogmas of laissez faire liberalism that had commanded in the previous decades:

Even by resorting to all the organizational and technical measures of implementation, if we do not simultaneously lower the interest rate, we will not be in a position to reduce the affections of new housing to a bearable level. Therefore, the State will have to provide for the construction of houses for the minimum level of life, since, otherwise, there will be no certainty that the financial subsidy measures, which must be taken by the State, benefit those whom they are intended to. (Ernst May, cited in Aymonino, 1971; authors' translation)

May's concern embodied the unanimous call from within the CIAM for the intervention of public political bodies (the State and municipalities administrations) to solve the housing crisis. If the idea of Existenzminimum proved to be a useful theoretical umbrella to compact progressive positions against housing speculation and workingclass inhuman living conditions, personal contributions enlightened contrasting agendas (Gubler, 2012). The difficulty to spatially translate a programmatic view with social, cultural, and economic implications into a definite architectural project was, once again, clarified by May himself:

How should the home for the minimum standard of living be? For now, it is almost impossible to give a positive answer to this question; it is instead possible to answer in a negative way. (Ernst May, cited in Aymonino, 1971; authors' translation)

The negative way mentioned by Ernst May meant the utter refusal of all the hygienic shortcomings, socially oppressive character and deficiencies of Nineteenthcentury dwellings; the possibility to develop a positive program for the Existenzminimum remained, instead, open to architects' projects and interpretations.

During the Frankfurt debate, Le Corbusier and Pierre Jeanneret emphasized the impact of modern construction techniques on the spatial rationalization and biological solution of the domestic problem:

Housing is a biological phenomenon. However, the rooms and the spaces it entails are defined by an envelope that obeys a static rule. The biological fact and the static fact are part of two different orders....If the traditional methods are maintained for which the two functions are confused and interdependent, we will remain in the same immobility: a) the industry will not be able to take possession of the "maison minimum"; b) architects will not be able to do projects suitable for the modern economy. (Le Corbusier and Pierre Jeanneret, cited in Aymonino, 1971; authors' translation)

For the Swiss architects, the Existenzminimum embodied the full realization of modern living and of the social possibilities of Modern Architecture. This was only possible in light of the most advanced processes of industrial production and building-site realization. The "maison minimum" presented at the 1929 II CIAM was the application to specific social problems of the iterations on constructive principles that Le Corbusier had previously developed throughout the 1920s (Le Corbusier, 1996), from the paradigmatic Maison Dom-Ino to the formalization of the Le Corbusier's five points on modern architecture in 1927.

The biological implication of a new type of dwelling was a common viewpoint in Walter Gropius's analysis, although the German architect insisted on the social order of target household, namely the urban dweller:

The development of the minimum dwelling has come to a standstill, evidently due to the fact that I do not consider with sufficient attention the profound changes in the social structure of nations. (Walter Gropius, cited in Aymonino, 1971; authors' translation) 
Connecting biology and sociological progress, he referred to positivistic socio-economic position borrowed from Müller-Lyer, linking the modern dwelling to the historical evolution from tribal communities to socialindividualism (Poppelreuter, 2011). Focusing on the demographic shift and changes in the field of production caused by industrial capitalism, Gropius argued against the traditional forms of family living towards the necessity of producing lodging houses with collective services for working individuals. In Gropius's mind the goal was set:

Egoistic individualism is replaced by social individualism. The "complete" individual becomes the purpose of the State, the structure of society is the means to realize this goal. (Walter Gropius, cited in Aymonino, 1971; authors' translation)

In light of these observations, it is possible to interpret his projects. For example, his designs for apartment housing with collective facilities in 1929-1931, can be interpreted as a reformist device (Agamben, 2006) to shape a new type of proletarian subject, endowed with a mix of bourgeoise ideals and collective sensitivity in the name of a common good and the future prosperity of the social order.

Biological concerns and social implications were integrated by the Belgian architect Victor Bourgeois in his elaboration of the problem of domestic labor, linking industrial production and domestic reproduction:

While in industry, rationalization has as its main goals the increase in production and the decrease of cost prices, in the domestic organization, it seeks to simplify the duties of the housewife, reducing fatigue. (Victor Bourgeois, cited in Aymonino, 1971; authors' translation)

With the increasing impact of the housekeeping burden on housewives and the acknowledgment of the house as a crucial apparatus for social and economic efficiency, the Belgian representative understood the house as part of a larger mechanism of social reproduction, suggesting the development of "home management education" programs as a necessary didactic tool to form optimal households.

The plethora of positions discussed in Frankfurt, as well as the extensive research done by a network of architects, spread all over Europe, found in the itinerant exhibition and in the publication produced at the end of the congress, in 1930, an apparently coherent synthesis, mitigated by the uniformed representation graphic method (uniform hatches and drawings integrated with captions and numbers). The sensation of an "unfinished project" graspable by the comparison between an analysis of congress debates and the agenda of the final output is symptomatic of the far-reaching ambitions of the II CIAM and its inevitable shortcomings. Rather than a singular proposal for the Existenzminimum, the outcome can be intended as an atlas of visually similar solutions, an editor's selection of "best practices" (Figure 2), where plan representation subsumed a series of common concerns on the reduction of surface and construction costs, problems of dwelling distribution, flexibility, and domestic labor.

Outside official congress proceedings and exhibitions, and even in reaction to them, additional investigation on the minimum dwelling was attempted. Two figures in particular, Alexander Klein and Karel Teige, developed autonomous lines of research and design to envision a project for the living unit alternative to the one proposed by CIAM. In order to counterpoint the outcome from Frankfurt and to enlarge the arena of debate, we suggest an overview of the contributions of these distant and lesser-known figures as the most representative and synthetic approaches to the housing debate from Modern Movement to today. In parallel, but outside the congresses, both developed opposite visions that helped to highlight the latent projective potentials of minimum dwelling as presented by the II CIAM.

\section{Alexander Klein: Rationalization for Frictionless Living}

Between the mid-1920s and the early 1930s, Alexander Klein pioneered an approach to minimum housing design based on life and movement abstraction through the application of Taylorism principles (Maier, 1970; Taylor, 1911) and systematic methodological experimentation. Forgotten by the chronicles of modern architecture, the radical consistency of Klein's work has been crucial to the research on minimum working-class dwellings in Weimar Germany (Miller-Lane, 1968) and cast a long shadow on post-war housing theory. His work paralleled, and subtly critiqued, early CIAM investigation on the Existenzminimum, developing scientific evaluation and design methodologies as guidelines for the architecture of minimum dwellings (Klein, 1975; Stöhner, 1976).

The desire to revise housing design, with the intent to optimize both its production and internal arrangement, led Klein to carefully apply the principles developed by scientific management to his professional work. In 1911, Taylorism theorized a scientific method for labor discipline and workshop management, based on the optimization of workers' efficiency, in order to increase manufacture productivity (Taylor, 1911). The qualifying aspect of scientific management lay in the analytical method through which the labor process was dissected and analyzed in elementary spatial and temporal components, allowing achieving an optimization of the whole process. Rather than a revolution of the means of production, Taylor envisioned a reform of the productive process based on a reassessment of the very source of capital surplus, namely "living labor". The adoption of scientific management imposed a mental revolution on the understanding and design of domestic space that cast a 

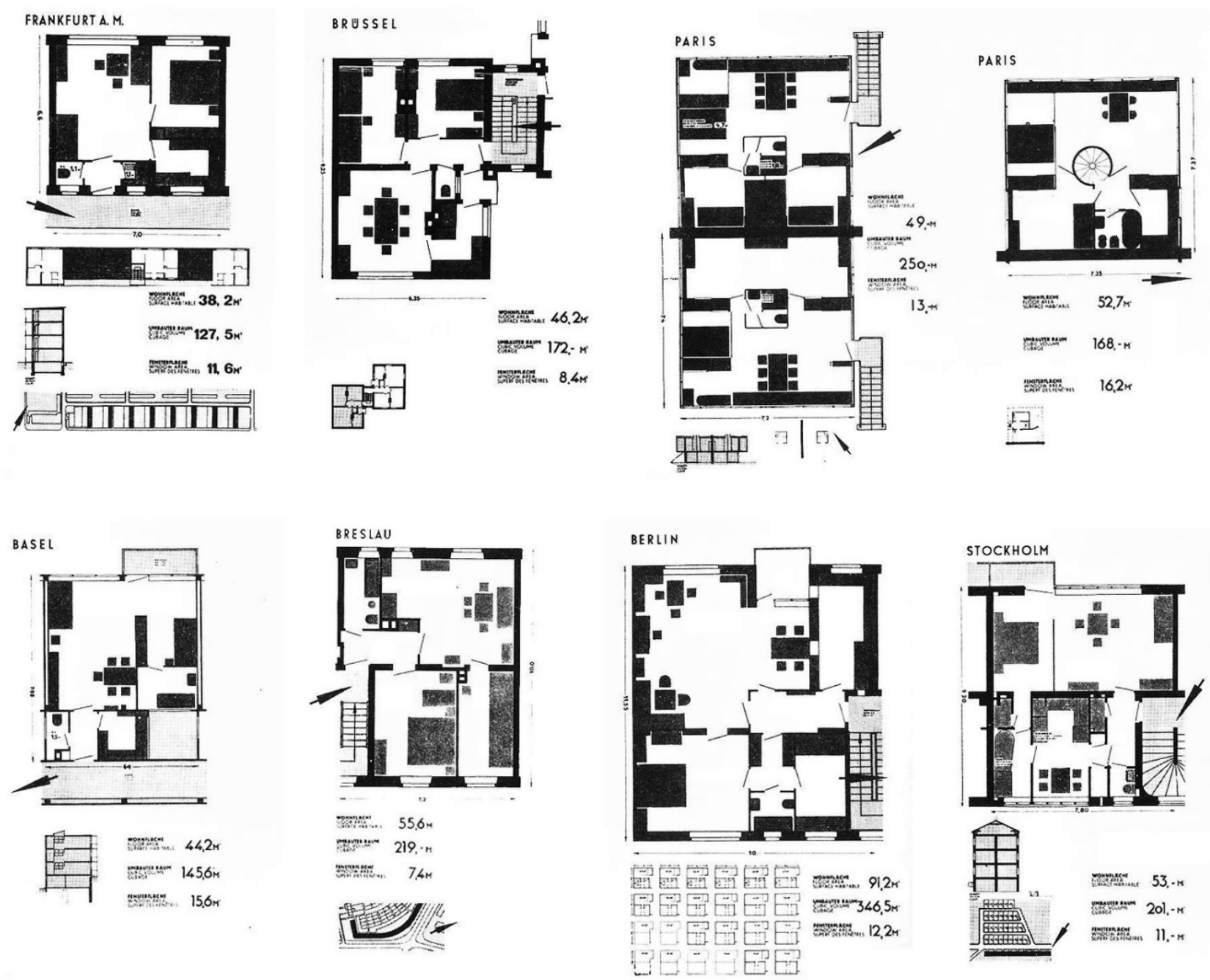

Figure 2. Existenzminimum dwelling. From II CIAM (Frankfurt, 1929), exhibition panels. Source: Aymonino (1971).

long shadow over the evolution and agendas of modern architecture in Europe.

In his book, Mechanization Takes Command, Giedion (1948) traced the origins of modernity in the development of anonymous attitudes and practices: rather than groundbreaking monuments or a revolutionary event, he noted that the modern ethos was characterized by the attempt to geometrically describe and govern movement through abstraction. The case of Morey's methods and, most importantly, of Frank Gilbreth's graphic experiments (Figure 3) is significative to understand the manner in which movement description gained crucial importance in the debate on domestic space since the end of the 19th century (Giedion, 1948, pp. 14-44).

Alexander Klein engineered a systematic scientific approach to housing design based on the optimization of domestic space through statistic and drawing analysis, emphasizing this typically modern displacement of the identity between subject and movement. Indeed, for him, the problem with housing was not simply a matter of shortage, but mostly of the rationality of its internal spatial arrangement. In his 1928 Grundrissbildung und Raumgestaltung von Kleinwohnungen und neue Auswertungsmethoden, the German architect presented a novel systematic method for designing minimum typologies (Klein, 1975, pp. 76-99). His approach was characterized by the will to tackle the problem of dwelling rationalization independently from constructive and material problems: the living-unit is considered a space for the scientific organization of life.

Thanks to an original tripartite method integrating evaluation questionnaires, comparative analysis, and graphic interpretations, Klein outlined a detailed program to produce objectively valid, affordable, and comfortable minimum dwellings. A preliminary questionnaire would have allowed for a qualitative evaluation of the existing housing stock according to dimensional parameters and established ratios. The comparing activity performed through a series of plans redrawing using the same scale, allowed to compare specific architectural aspects and to decide on the best solutions. The graphic method was instead used as an operative tool to investigate the internal functioning of the house, representing inhabitant movement, airflow, sun exposure, or the im- 


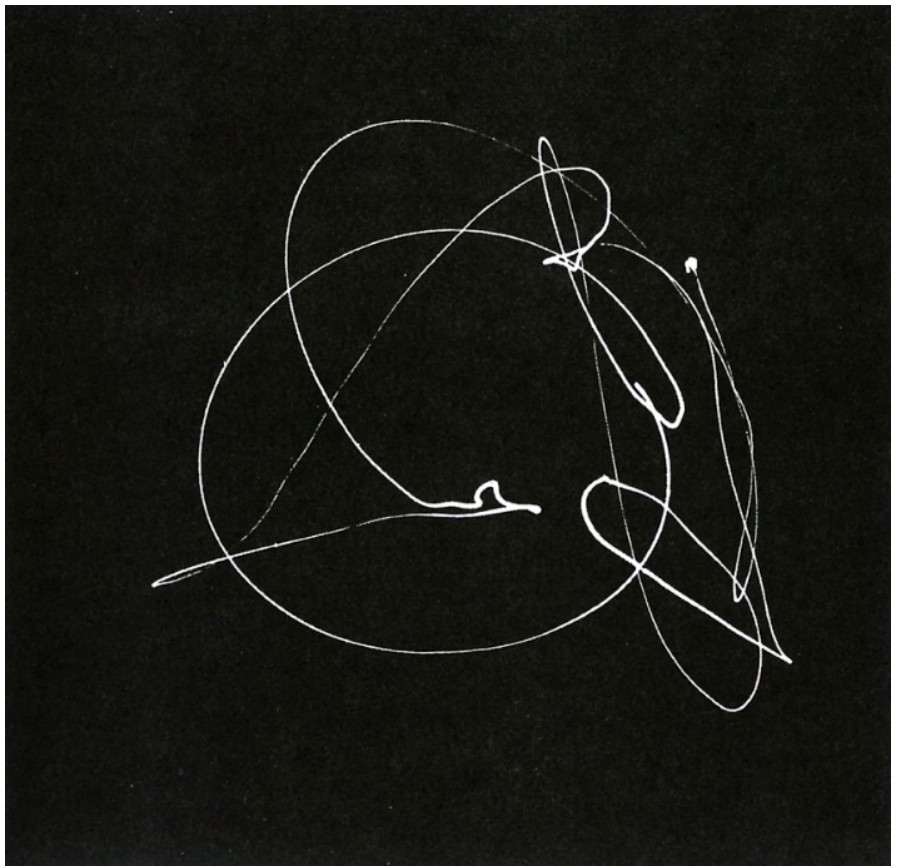

Figure 3. Cyclograph record of the path of a point of a rapier used by an expert fencer, by Frank Gilbreth. Source: Giedion (1948).

pact of furniture distribution on the internal space. The parallel between Taylorism methods and the Klein approach is evident in the cross-hybridization of different methodologies and media (diagrams, data collection, redrawing), which allowed the German architect to evaluate and foresee the impact of the architectural decision on the domestic performances: similar to the factory manager, the role of the architect is to analyze existing conditions, compare them, and choose, using a positivistic approach, an optimal disposition to avoid undesired friction within the domestic machine (Evans, 1997). Representation of inhabitants' movements within the dwelling unit enabled the architect to visualize trajectories and opt for the optimal solution (Figure 4); studies on sun exposure made a reconsideration of the unit's depth and openings' dimensions possible; figure-ground representation of furniture disposition suggested the maximization of usable surfaces in contrast to the fragmented confusion of historical interiors (Klein, 1975, pp. 77-109). In this process, the feedback loop between observation, measurement, representation, and optimized solution tends to minimize the impact of subjective parameters and to establish an autonomous process to determine the rationality of the house, binding together the biological improvement of households, their performances in the domestic sphere, and the possibilities offered by local construction industries.

Anticipating the CIAM exhibition, Klein used plans and diagrams to demonstrate his arguments almost exclusively. In addition, we can't fail to recognize the similarity between the way he represents domestic space, and its impact on inhabitants (movements, furniture, light, and air), and the technique developed by the Gilbreths to physically represent dynamism.

Klein's approach merges analysis and design into a continuous process: from an objective evaluation of existing problems, it is possible to define precise questions and solve them thanks to standards and spatial optimization. Abstract parameters can be easily applied to different mass housing programs. In contrast to the 1929
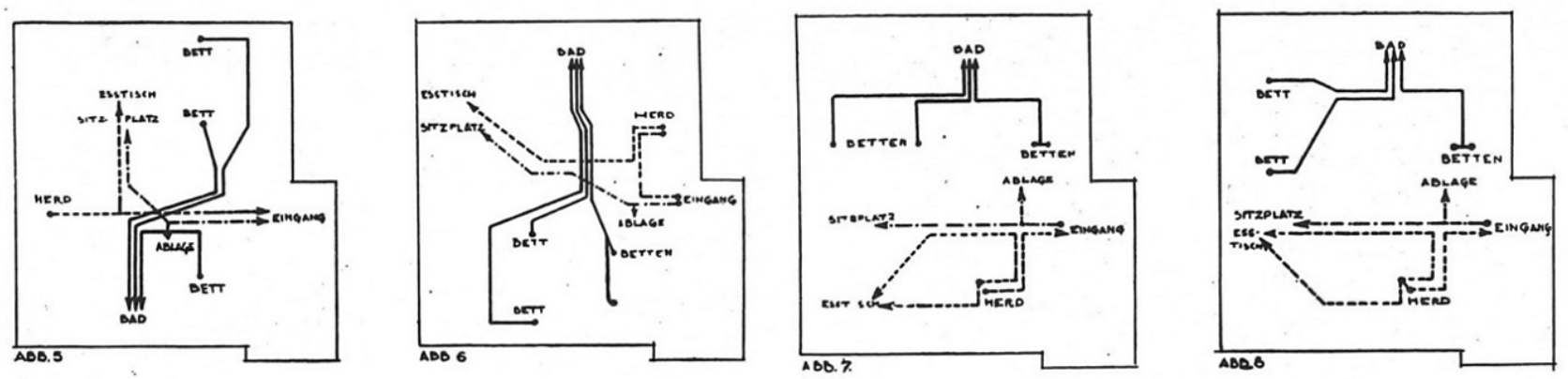

Figure 4. Graphic method for the optimization of dwellings internal circulation. Source: Klein (1928). 
exhibition, rather than proposing finite examples representing best practices in the field of housing reform, his method explicitly puts forward an anonymous and objective methodology to obtain what he considered to be an adequate living unit (Figure 5). Housing design becomes a parametric and continuous process.

As an answer to the rising housing crisis in the period of the Weimar Republic, Klein was a convinced supporter of the need for public intervention to regulate the housing market. His investigations, beginning in the years 1927-1928 and formalized in 1930 with the article Beitrage zur Wohnungsfrage als praktische Wissenschaft, were carried out from within the Reichsforschungsgesellschaft (German National Society For Scientific Research). The Weimar Germany Public Research Agency demanded to test economic and constructive solution to innovated cheap housing production. The work Klein developed with other architects, like Walter Gropius, within this organization, focused on the need to integrate design research with the political and productive interests of public structures, local administration, or social initiatives (Klein, 1975, pp. 100-113).

Embedding housing design in national policies and actors determined the rationale of research endeavors and the outcomes it generated, questioning the role and competences of architects from artifact designers to organizers of complex processes in the wider frame of State social-democratic policies.

The development of scientific parameters for the evaluation of dwellings' spatial qualities and the design tools for their optimization, also allowed Alexander Klein to formulate a subtle critique of CIAM and subsequent Modern housing projects. First of all, the adoption of an objective method to evaluate housing impact on inhabitants' performances enabled Klein to question the supposed functionality of Modernist dwellings. His proposal to revisit the plans of Oud's Weissenhofsiedlung units according to the principles established in his Grundrissbildung in 1927 is exemplary (Klein, 1975, pp. 110-113). Using the graphic method, he decom-

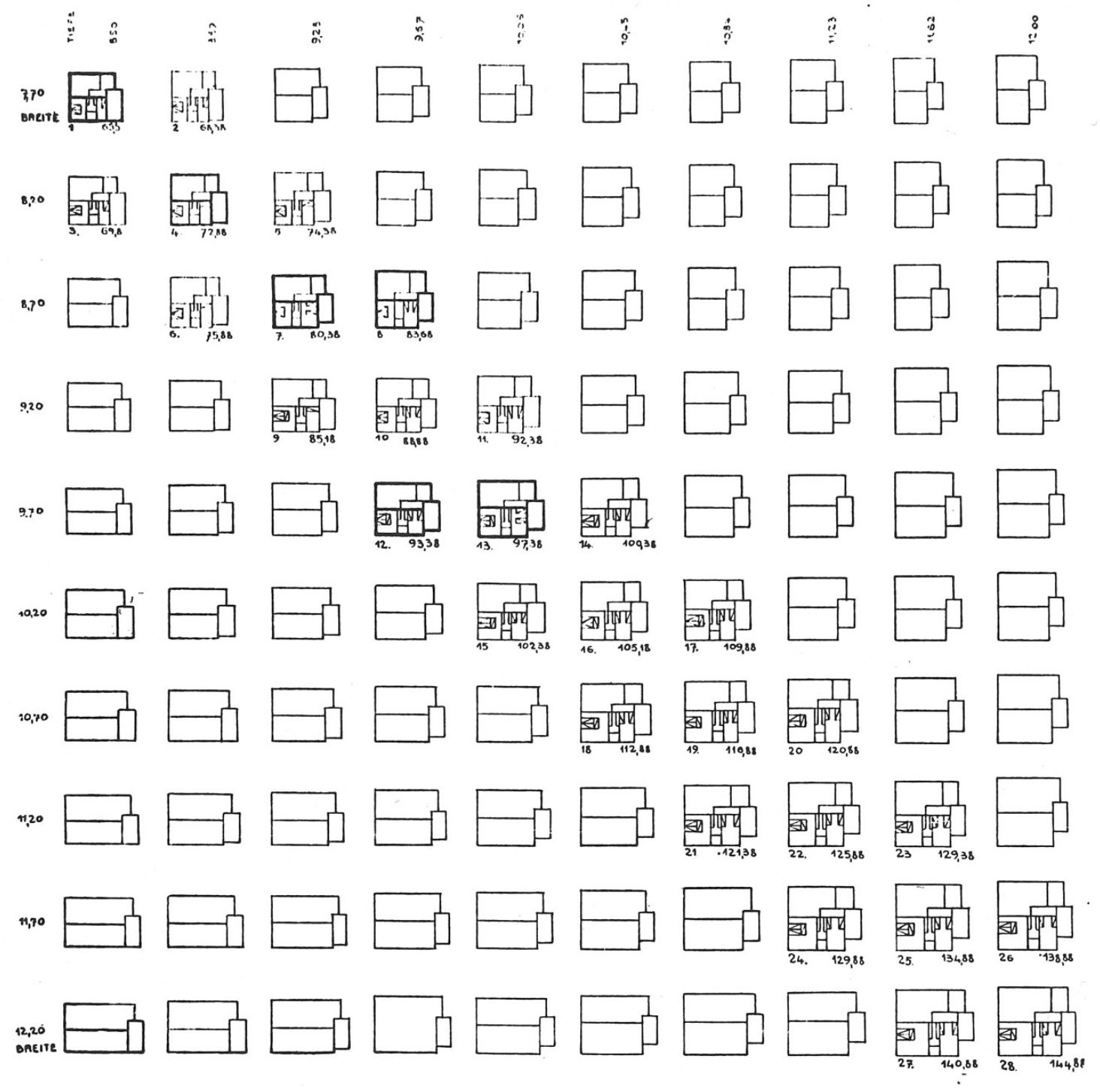

Figure 5. Plan-efficiency comparison. Source: Klein (1928). 
posed Oud's units showing the fragmentation of spaces, the disturbing overlapping of users' trajectories, and an over-presence of unusable surfaces contrasting with the presented qualities of functional rationality. As a demonstrative exercise, he also showed that an optimization of the Stuttgart unit, according to his method, is possible with minor effort. Secondly, the systematic discourse developed by the German architect contrasted with the fragmented and strongly individualized proposals debated in Frankfurt in 1929. In his opinion, the Existenzminimum project should not have been limited to investigations pursued by stand-alone architects. On the contrary, it should have become an objectified series of methodological rules, universally applicable to allow for maximized domestic performances.

For Klein, the rationalization of the minimum dwelling was not only a moral necessity to answer the biological issues; it was an operative method to reach a clear socio-economic agenda: the creation of a frictionless domestic space able to optimize workers' reproduction. The development of rational constructive and distributive approaches, the definition of standards and of manual-like applicative principles, defined housing as an apparatus to embed social bonds with a capitalist economy.

Unlike other contemporary architects, Klein did not question the familiar household (Bevilacqua, 2011; Poppelreuter, 2011; Teige, 2002; Klein, 1934). Rather than the social unit, his targets were the relationships between household members and the unfolding of familiar everyday existence in the domestic setting. The goal was to turn the house into an "anabolic" instrument, an environment to maximize working-class rest and reproduction (Klein, 1975). By applying a scientific approach to the design of the minimum living unit layout, it was possible to plan life as a process that needs to be seamlessly performed. The separation of functions in day and night areas, the optimization of spatial use through a careful analysis of inhabitants' movement trajectories and distances, the necessity to favor health regulations and livability standards: these aspects were meant to grant not only physical recovery, but, and this is a feature that Klein strongly stresses, psychological peace.

While modernity detached productive activities from the living unit, Klein recognized the overlapping of life reproduction and industrial production in housing itself and theorized their continuity through design. Arguably, with no other modern architect does the house assume such a clear agenda within the productive system, not simply as an artifact but as an apparatus for the reproduction of a productive form of life, as it does in the work of Alexander Klein.

\section{Karel Teige: Political Program for New Forms of Dwelling}

Karel Teige's contribution to the CIAM discourse was represented by his emblematic book Nejmenši byt (The Minimum Dwelling). The book, published in 1932, three years after the II CIAM, presented Teige's critical position regarding the Existenzminimum: in it, he accused modern architects of proposing only resized versions of bourgeois single-family houses and readapting their lifestyles to the proletariat. The functional subdivision of the house into kitchen, living room, and bedrooms, mirrored the division of labor between family members, thus reproducing an inadequate model for the new ways of life of the proletariat (Teige, 2002). He especially criticized the kitchen as the emblem of what was starting to be considered the exclusive sphere of women's occupation: domestic and affective labor. In fact, if we consider approaches such as the scientific management of the home introduced by the work of Christine Frederick in the 1910s, which can be found in the seminal Frankfurt kitchen prototype designed by architect Margarete Schütte-Lihotzky in 1926, it is arguable that our contemporary conception of house as separated from work has its origin in Fordism modernism (Frederick, 1914; Schütte-Lihotzky \& Kinchin, 2011, pp. 86-96).

Karel Teige's contribution to the modern debate can be interpreted as a clear political position and as an attempt to suggest new architectural forms of collective living. In his essay for the III CIAM (in Brussels, 1930) proceedings, Teige expressed his argument that the housing shortage was related to the insufficient number of lodgings for the classes of the minimum level of life (Teige, 1971, pp. 208-215)-the proletariat and the intelligentsia. Starting with Engels's seminal essay The Housing Question, and by adopting a Marxist materialist analysis of history, Teige insisted on the necessity to develop an analytic methodology for the domestic project, based on preliminary statistics and empirical research. He accepted Engel's revolutionary vision and thus insisted on a radical solution to the problem of the minimum dwelling: the collectivization and the centralization of all aspects related to domestic labor (cooking, housekeeping, childcare, services) and the reduction of the private space to a single living cell-the universal room (Aureli \& Tattara, 2019; Aureli, Tattara, \& Korbi, 2018). This latter was, for Teige, the very political content of dwelling and it was very effectively abstracted in the diagram of the collectivist reconstruction of dwelling (Figure 6).

In the first part of his 1932 book, diagrams, graphs, and tables were used to illustrate the overall historical conditions of the housing crisis in different European cities and the problematic contrast between traditional housing and the rise of new modus vivendi. Unlike Klein, diagrams become, for the Czechoslovakian poet, a vehicle to make a clear political and programmatic statement and to give a clear form to qualitative data analysis and concepts. In strong contrast with the neue Sachlichkeit ("new objectivity") and its translation into design, he saw functionalism as the translation of the assembly line logic (through the mechanization of labor) within the organizational model of dwelling (Dluhosch \& Svacha, 1999). 


\begin{tabular}{|l|l|c|}
\hline kitchen & dining & $\begin{array}{c}\text { salon }= \\
\text { club }\end{array}$ \\
\hline $\begin{array}{c}\text { house- } \\
\text { keeping }\end{array}$ & bathing & $\begin{array}{c}\text { children's } \\
\text { space }\end{array}$ \\
\hline services & $\begin{array}{c}\text { physical } \\
\text { culture }\end{array}$ & $\begin{array}{c}\text { individual } \\
\text { living } \\
\text { cell }\end{array}$ \\
\hline
\end{tabular}

\section{Collectivist reconstruction of dwelling}

Schema of a collective dwelling:

the centralization and collectivization of the economic, cultural, and social factors of the dwelling process;

the reduction of the "apartment" to an individual living cell. One room for each adult person,

whose content (function) is a living room and a bedroom;

the reproduction of a single space undifferentiated dwelling on a higher level;

material and organizational basis for socialist forms of life.

Figure 6. The collectivist reconstruction of the dwelling. Source: Teige (1932).

Moreover, the last part of his book can be read as an architectural manual. The collectivization of all aspects of family living was only radical when compared to the general ethos of Modern architects. The new forms of collective dwelling proposed by Teige were illustrated through a collection of several heterogeneous architectural examples presented with a variety of representation techniques: images, plans, and axonometries. The order in which they unfold in the text also reveals a gradual evolution towards the total collectivization of living, from embryonic examples of historical and modern boarding houses to the American skyscraper-hotel and the soviet Dom-Kommuna experience. Whereas boarding houses provided only a room and a few services, offered by their family owners, the American skyscraper Hotel and the soviet Dom-Kommuna (communal-house) represented the apogee of what Teige intended with the expression "collective house": a place where domestic labor and work in general was organized as social labor and living was reduced to a mere sleeping chamber (Teige, 2002, pp. 323-393).

Indeed, Teige knew very well that during the $1910 \mathrm{~s}$ and 1920s in many American metropolis, the intense presence of individual white-collar workers, bachelors, and businessmen corresponded to a massive diffusion of standardized commercial hotels. The alphabetical form of many American generic metropolis resulted from adopting standard schemes (H-, I-, U-, E-shaped) that consented that the "only" way to have an efficient entrepreneurial machine for living within the capitalism of the Progressive Era (Davidson, 2005, pp. 72-103; Holl, 1997). In Manhattan, hotels were concentrated in every neighborhood and every individual could easily find a room for a "few dollars" in walking distance from his or her working place or close to a railway station. For example, the Biltmore Hotel (1913), designed by the Warren and Wetmore firm, was built as part of New York
Grand Central masterplan and the hotel lobby was directly connected to the station. Hotels like The Biltmore corresponded to standard models of design and efficiency (Figure 7): the provision of a myriad of single rooms, restaurants, leisure rooms, and lobbies for working and collective meetings, was made possible by a complex backstage of mechanized domestic labor and by an "army" of professional staff providing housekeeping services.

The hotel organizational model was considered by the Organization of Contemporary Architects' soviet architect Moisei Ginzburg when he was working on the standardized living cells for the Strojkom (soviet residential department) of the RSFSR. At the end of the 1920s, soviet central institutions intended the minimum dwelling to be the only possible way to provide a universal dwelling for all, whereas for Ginzburg and other constructivist architects, it was the main condition for the program of the so-called Dom-Kommuna (Ginzburg, 1934). By following a scientific approach aiming at reducing and eliminating unnecessary spaces from a typical family apartment (see Figure 8), in 1928, Ginzburg designed different types of living cells, from the microapartment (cell $A$ in the figure) to the single room (cell E).

All of the experimental types were compared through an efficiency diagram, a sort of "gradient of sharing" where each cell presupposed the starting point for a more complex communal-house with large common areas and central services (kitchens, education, childcare, or cultural services; see Figure 9).

For Teige, the minimum dwelling was not only an architectural problem; it was for him an act-or, borrowing an expression from Giorgio Agamben-a "form of life", corresponding to different habits (Agamben, 2011). The possibility to act and perform life in different ways through different possibilities and architectural models constituted the very meaning of the term "universal 

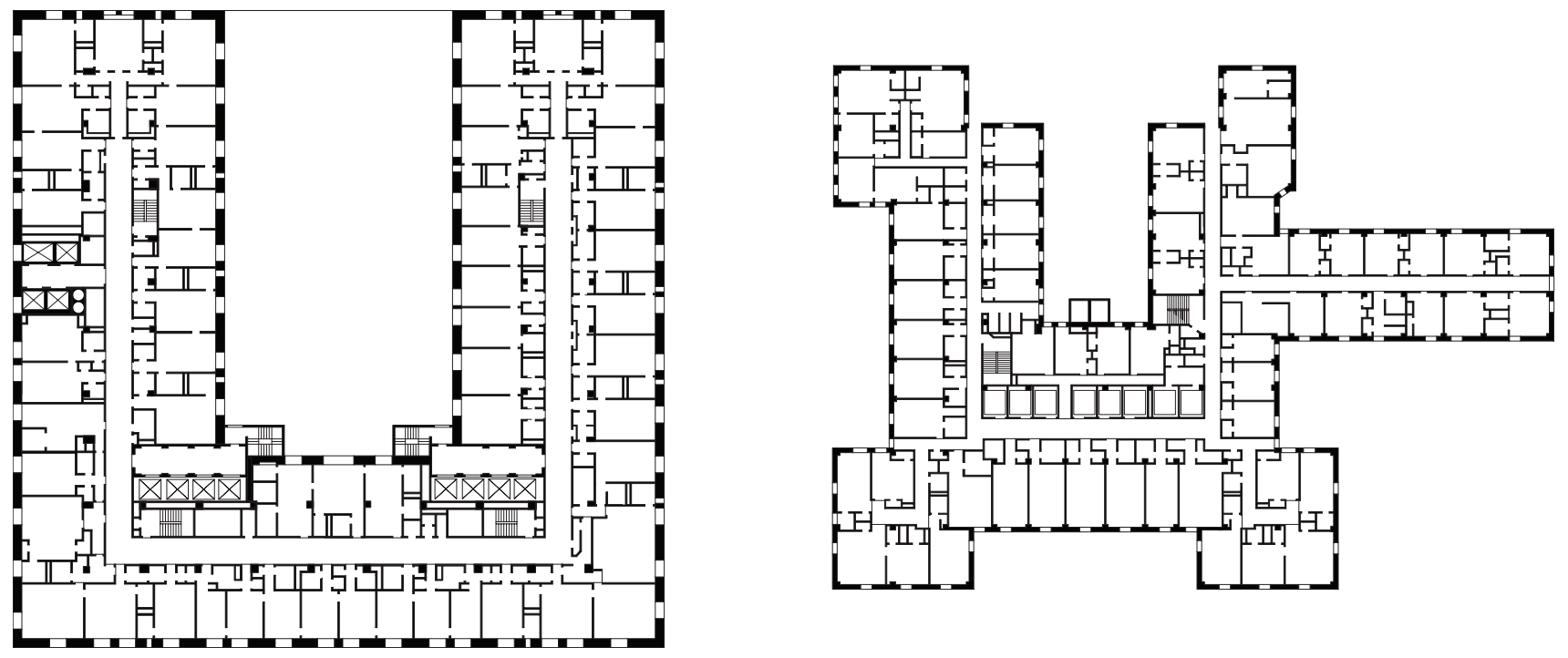

Figure 7. The hotel: standard models of design and efficiency. From left to right: plan of the Biltmore Hotel by Warren and Wetmore, New York, 1913; plan of the Shelton Hotel by Arthur Loomis Harmon, New York, 1924. Source: authors.

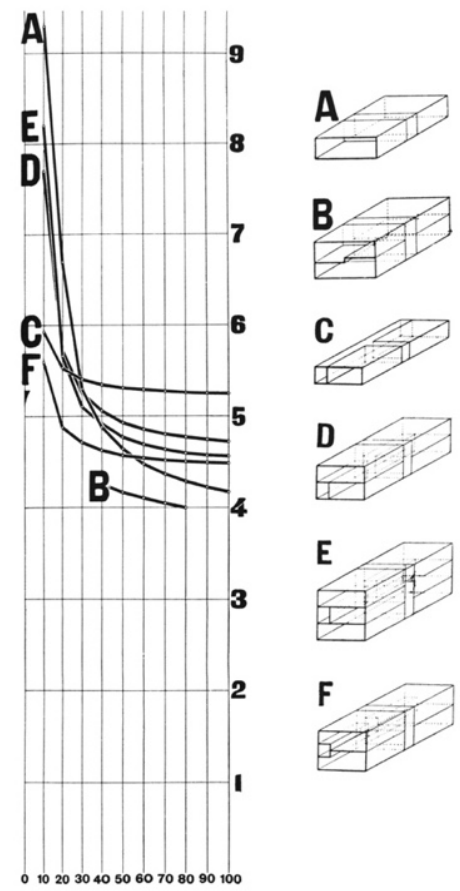

Figure 8. Diagram of economic efficiency of dwelling types, showing the ratio between the cubic volume of the building and the usable floor area of the units for every single cell (A to F). Strojkom of the RSFSR. Source: Ginzburg (1934).
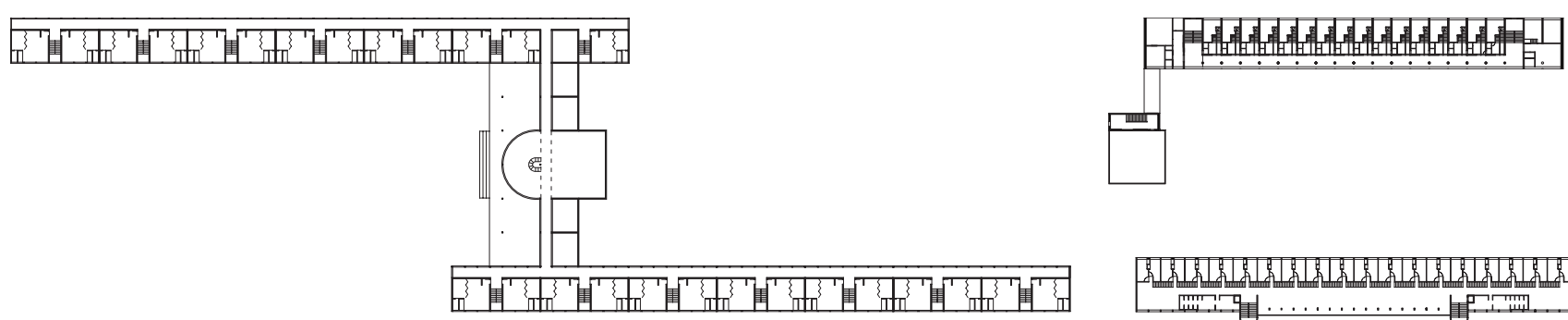

Figure 9. Prototypes by Ginzburg, Strojkom, 1928. From left to right: a plan of a Dom-Kommuna prototype with A-1 cells (one-room apartment); plan of the Narkomfin Building with F cells (top image) and prototype of a Dom-Kommuna with E cells (bottom image). Source: authors. 
dwelling". It can be interpreted in this way: the possibility to have a room for dwelling, for every individual, in every place, in every moment, for every different way of life-a sort of universal basic right. This interpretation, implicit in Teige's The Minimum Dwelling, gives the idea of how he understood Taylorism not as a schematic rationalization of life within the four walls of the family home, but as a mechanism to provide every adult with his or her private room within communal houses. Industrial mass production was for him an alternative to the way the II CIAM generally understood domestic space; it was the real political possibility to liberate life and dwelling from domestic labor.

\section{Practices of 'Minimum Dwelling' after the War}

Though Klein's work in Germany would be abruptly stopped by the affirmation of Nazism and Teige's critique would never be discussed due to the radical transformation of the CIAM between 1930 and 1933 (Ciucci, 1979, pp. 39-51), a review of their projects for the Existenzminimum and their polemic difference with the CIAM agenda provides us with lenses to interpret the fundamental evolution that housing theory and design witnessed after WWII.

In the years following WWII, with the advent of the welfare state, housing production was characterized by a fierce push for the rationalization of construc- tive and typological forms. This is recognizable in two crucial trends: the advent of mass-standardization and the renewed interest in architectural manuals. Public housing production in post-war Europe developed within Keynesian economic measures in an attempt to create a consumer market and sustain national prosperity, through the provision of universally dignified housing conditions (Avermaete, van den Heuvel, \& Swenarton, 2015, pp. 1-23; Urban, 2012). In this light, we should read the rising of "standards", abstract, technocratic parameters able to govern the different abodes of welfare state housing production: central political-technocratic powers, capitalists and industrial production, and household/consumers. Remanding to specific historical text for the detailed analysis of the chronicles of post-War housing in Europe (Cupers, 2014; Glendinning \& Muthesius, 1994; Liebscher, 2009), we can claim with a certain degree of generalization that, since the reconstruction period, a hypostatization of housing production and reproduction of living typologies has taken place (Figure 10).

Surviving the crisis of the Welfare state and the increasing reduction of public housing supply, the hypostatization of the modern living unit as a given and unquestionable model is still endlessly put forth. If Klein envisioned his method as a pragmatic framework to continuously question the qualities of the minimum dwelling vis $a$ vis the evolution of concrete relations between households, social-economic structure, and space, a post-War

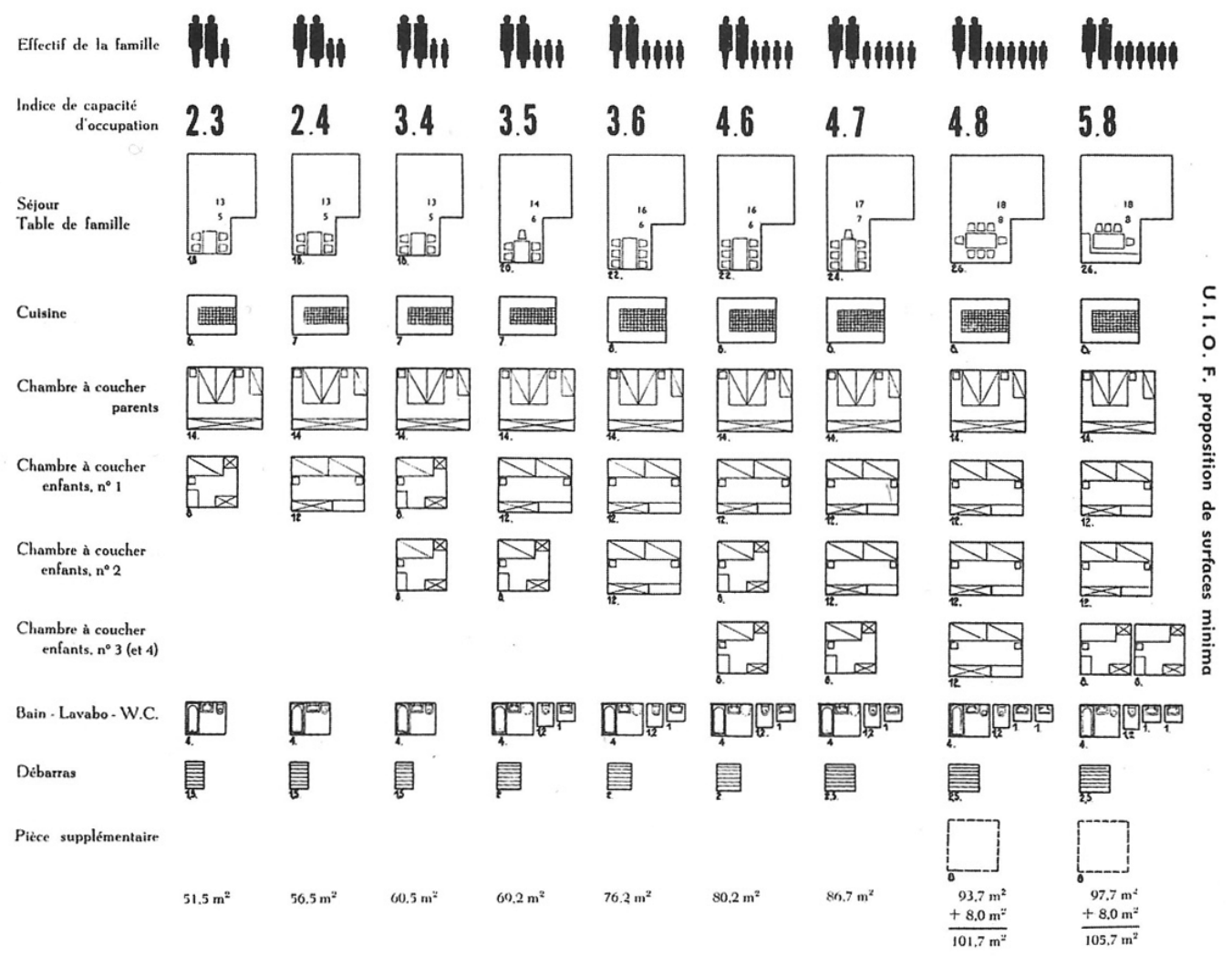

Figure 10. Diagram for the calculation of minimum surface norms for apartments in post-war France, first published in 1959 in Techniques et Architecture, 19(2). Source: Cupers (2014). 
technocratic approach has pursued rationalization to create ready-made solutions applicable by public or speculative bodies for universal users.

Regarding the standardization of housing typologies, and often related to Klein's research, there is also the post-war rediscovery of a traditionally architectural form of construction-oriented knowledge: the manual. In the 1950 s and 1960 s, manuals presented standardized solutions for housing distribution and size based on universally valuable, rational schematic representation (AA.VV., 1953; Ciucci \& Casciato, 1980, pp. 7-20; Gabellini, 2001, pp. 99-111; Marescotti \& Diotallevi, 1948). In a seminal article, Vittorio Ugo reflected on the importance and ambiguity of schemes in architectural manuals, recalling the importance of Klein's experiments (Ugo, 1986). If the scheme as a precise drawing embodying the genetic core of a project idea has been used as a heuristic tool until the 19th century, with the advent of modernity, it turned into an instrument used to directly translate reality onto paper, thus reducing representation to a merely operative tool. While Klein's activity lies at the threshold of this passage, the practices of housing production that followed, whether public or private, have generalized this standard-based approach, reducing architecture to a compositional exercise to promote market attractive housing typologies and the fossilization of social and reproductive bonds (the family in particular) into given spatial configurations.

Attempts to tackle this deterministic approach to housing started in the 1970s with the creation of new autonomous forms of domestic organization. Cohousing was the first reminiscence of collective dwelling after decades of obscurations and attention directed to family housing. The new model was invented at the end of

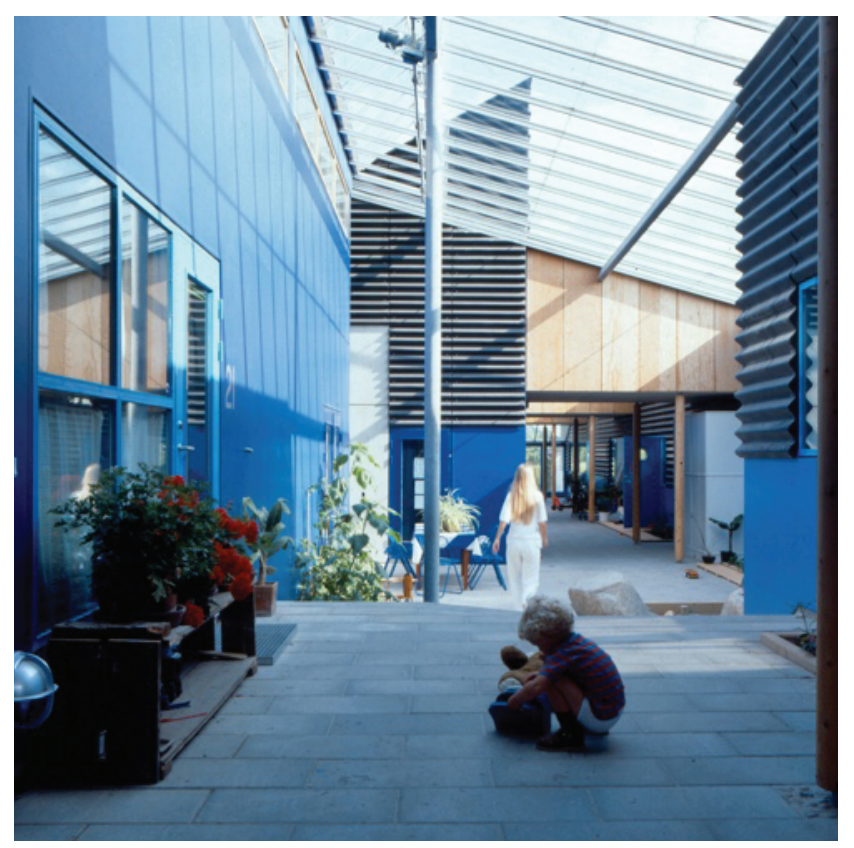

the 1970s in Denmark and the USA (McCamant \& Durrett, 1988 ) as an economical alternative to traditional mass housing and single-family homes. It was created by new groups of young working parents and the elderly who needed to combine productive and reproductive labor within suburban neighborhoods (McCamant \& Durrett, 1988, pp. 9-11). Although its innovative ethos was firstly promoted in Scandinavia, and only recently in other geographic areas, we can consider the cohousing spatial and organization model to be still too far from Teige's idea of collectivization: in cohousing, dwellers shared few common spaces, including a large kitchen, dining rooms, and playgrounds for children, while still conserving the idea of a self-sufficient single-house equipped with a private kitchen (exemplary is the 1984 Jystrup Savvaerket by Vandkunsten Architects; see Figure 11).

This aspect was related to the resident's financial capacities and needs in which collective facilities did not replace private ones, they led to the reduction of private areas (and costs) only, somehow doubling domestic labor and housekeeping fatigue, a fact that strongly collapses with Teige's principles of collectivization. The problem with cohousing, referring to Teige's idea and his radical critique, is the family subject, both as an obstacle for collective organization and as an economical structure reinforcing the ideology of private property. As Francesco Chiodelli and Valeria Baglione argue, although cohousing has lately been praised as a valid alternative to the private housing market, it remains a model that is generally limited to the middle class or wealthy groups of tenants (Chiodelli \& Baglione, 2014).

Outside the family structure, for many individual subjects (precarious, students, freelance), moneysaving represents the main reason behind the con-

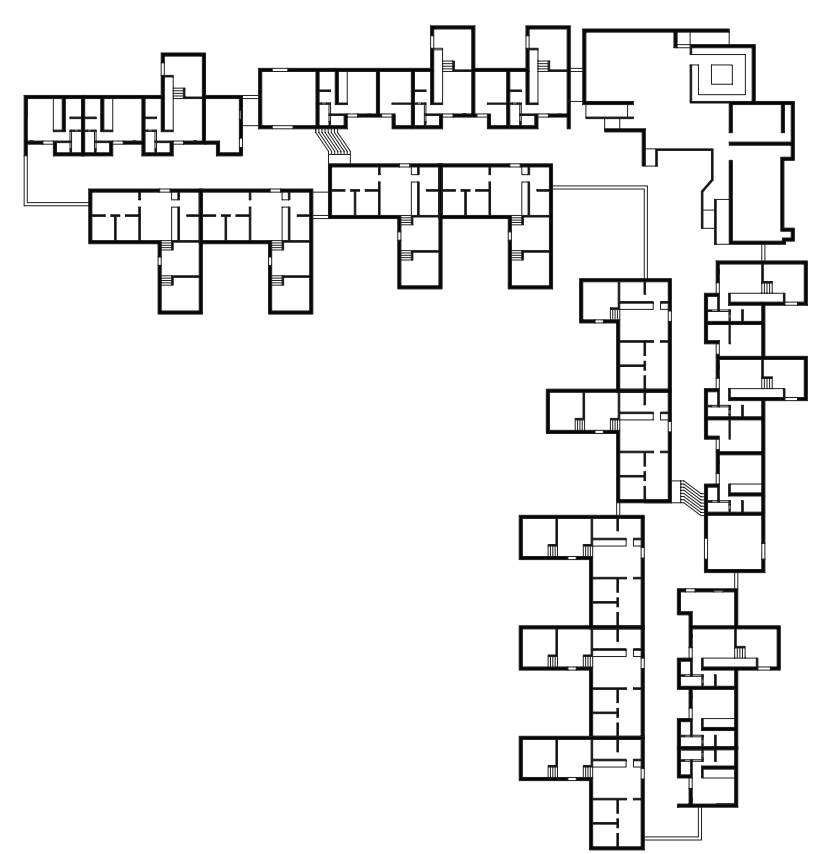

Figure 11. Cohousing Jystrup Savvaerket by Vandkunsten Architects, Denmark, 1984. From left to right: view of the collective space (Vandkunsten Architects, n.d.); cohousing typical plan (by the authors). 
temporary minimum dwelling and co-living examples. Whereas the former coincides precisely with what Teige strongly criticized-a miniature family-house-the latter becomes a dwelling solution out of necessity, generally associated with urban typologies such as the studioapartment or the micro-flat: places where production and reproduction, living and working, are condensed in one single room, gravitating around the single person (Macherez, 2015).

Forced by market possibilities, young generally precarious workers and students are forced to share small apartments (Figure 12). In Italy, this form of co-living is better known as the posto-letto ( "bed-place") typology where people pay for the very minimum, the bed (Gasparetto, 2017). This last model is the opposite version of the new fashion of hyper-designed and extremely domesticated commercial co-living in cities like London, New York, and even in Brussels or Rome (Aureli et al., 2018, pp. 254-255). It is arguable that the spread of many co-living, co-working, and the obsessive use of the prefix "co" has a strong relation with "cognitive capitalism" and its mechanisms of accumulation (based on cooperation, knowledge and cognitive labor), proposing a commercialized version of Teige's proposal.

\section{Conclusion}

Madden and Marcuse (2016) pointed out that, while nowadays the realization of housing depends mostly on private initiatives and speculative plans, the stateand politics - can't call themselves out of the market, since the commodification of housing is itself a "political project". In fact, politics and governments create not only rules but also enforce relations of contracts and regimes of properties between a myriad of actors: owners, investors, and tenants. The so-called "withdrawal of the public" has represented more of an institutional avoidance of housing as a social project, than an effective shrinking of public influence on issues related to the housing crisis.

This situation has profound consequences on the current understanding of housing from within architecture. Here lies the paradox: although domestic space is the field where architectural culture is mostly active, decades of neoliberal policies and market hegemony in housing production have drastically limited the space for concrete realizations.

The redefinition of a public framework through which alternative affordable housing programs could be realized should be coupled with the re-engagement of architects into the socio-political scene. The discussion on the Existenzminimum through the work of Alexander Klein and Karel Teige suggests the need to strategically embed and test housing projects with productive and social conditions of a given historical moment. When this happens, as demonstrated by contemporary cases, not only it is possible to define novel paradigmatic operational models based on collective living and questioning of property regimes (Meehan, 2014; Vey, 2016), but also to test novel typologies of domestic space (Boudet, 2017; Lacaton, Vassal, \& Druot, 2007).

We argue that a study of household forms of life and of their labor relations can be the base for structuring a new approach to housing theory and design, considering it as the environment where the struggle between productive economic interests, collective bonds, and households' modus vivendi are re-negotiated. In this framework, the minimum dwelling, the ultimate frontier of contemporary passive exploitation (Negri, 2012; Vercellone, 2008) acting through rents and labor, could also be rethought as a possible instrument of emancipation and, eventually, even as an architectural answer in the fight for a true "right to housing" (Pattillo, 2013).
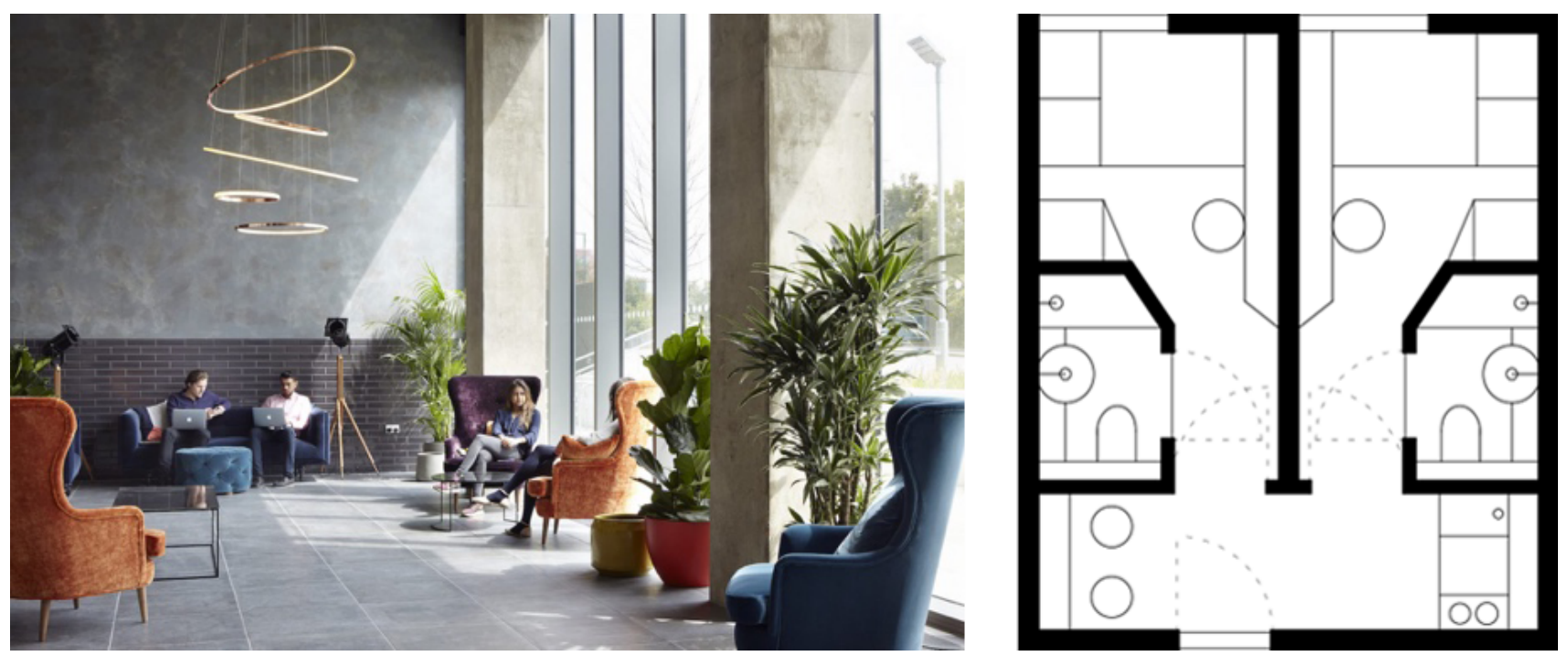

Figure 12. The Collective Old Oak, London. From left to right: communal space (Popupcity, 2016); typical room for singles with a kitchen shared by two units (by the authors). 


\section{Conflict of Interests}

The authors declare no conflict of interests.

\section{References}

AA.VV. (1953). Manuale dell'architetto [Manual for architects]. Rome: CNR-National Research Council.

Agamben, G. (2006). Che $\cos ^{\prime} e^{\prime}$ un dispositivo? [What is an apparatus?]. Rome: Nottetempo.

Agamben, G. (2011). Altissima povertà: Regole monastiche e forma di vita [The highest poverty: Monastic rules and form of life]. Vicenza: Pozza.

Allan, G., \& Crow, G. (Eds.). (1989). Home and family: Creating the domestic space. New York, NY: Palgrave MacMillan.

Ariès, P. (1996). I segreti della memoria. Saggi (19431983) [The secrets of memory. Essays (1943-1983)]. Florence: La Nuova Italia.

Aureli, P. V., \& Tattara, M. (2019). Loveless. Minimum dwelling and its discontents. Milan: Black Square.

Aureli, P. V., Tattara, M., \& Korbi, M. (2018). Loveless: A short history of the minimum dwelling. London: Design Museum.

Avermaete, T., van den Heuvel, D., \& Swenarton, M. (Eds.). (2015). Architecture and the welfare state. New York, NY: Routledge.

Aymonino, C. (Ed.). (1971). L'abitazione razionale. Atti dei congressi CIAM 1929-1930 [Rational dwelling. CIAM conference proceedings 1929-1930]. Venice: Marsilio Editori.

Bellicini, R. (2009). Ritorna il problema della casa [The return of the housing problem]. Casabella, 774, 12-15.

Bevilacqua, M. G. (2011). Alexander Klein and the existenzminimum: A "scientific" approach to design techniques. Nexus Network Journal, 13(2), 297-313.

Bologna, S. (2007). Ceti medi senza futuro? Scritti, appunti sul lavoro e altro [Middle classes without future? Writings, notes on work and other topics]. Rome: DeriveApprodi.

Boudet, D. (Ed.). (2017). New housing in Zurich: Typologies for a changing society. Zurich: Park Books.

Bullock, N., \& Read, J. (2011). The movement for housing reform in Germany and France, 1840-1914. Cambridge: Cambridge University Press.

Caudo, G., \& Sebastianelli, S. (2009). L'Italia cerca casa/Housing Italy. Milan: Electa.

Chiodelli, F., \& Baglione, V. (2014). Living together privately: For a cautious reading of cohousing. Urban Research \& Practice, 7(1), 20-34.

Ciucci, G. (1979). Architettura, socialdemocrazia, Olanda 1900-1914 [Architecture, socialdemocracy, Holdan 1900-1914]. Venice: Arsenale Cooperativa Editrice.

Ciucci, G., \& Casciato, M. (1980). Franco Marescotti e la casa civile. 1934-1956 [Franco Marescotti and the civil house. 1934-1956]. Rome: Officina Edizioni.

Cupers, K. (2014). The social project: Housing postwar France. Minneapolis, MN: University of Minnesota
Press.

Davidson, L. P. (2005). Early twentieth-century hotel architects and the origins of standardization. The Journal of Decorative and Propaganda Arts, 25, 72-103.

De Decker, P., \& Dewilde, C. (2010). Home-ownership and asset-based welfare: The case of Belgium. Journal of Housing and the Built Environment, 25(2), 243-262.

Dluhosch, E., \& Svacha, R. (1999). Karel Teige/1900-1951: L'enfant terrible of the Czech modernist avant-garde. Cambridge, MA: MIT Press.

Doling, J., \& Elsinga, M. (2013). Demographic change and housing wealth: Homeowners, pensions and assetbased welfare in Europe. Dordrecht: Springer.

Engels, F. (1872). Zur Wohnungsfrage [The housing question]. Leipzig: Der Volksstaat.

Evans, R. (1997). Translations from drawing to building and other essays. London: Janet Evans and Architectural Association Publications.

Frederick, C. (1914). The new housekeeping: Efficiency studies in home management. New York, NY: Double Day, Page \& Company.

Gabellini, P. (2001). I manuali: Una strategia normativa [Manuals: A regulatory strategy]. In P. Di Biagi (Ed.), La grande ricostruzione: Il piano Ina-Casa e I'Italia degli anni cinquanta [The great reconstruction: the Ina-Casa program and Italy in the 50s] (pp. 99-111). Rome: Donzelli Editore.

Gasparetto, G. (2017, October 31). Immobiliare: Affitto stanze studenti, cosa succede in Italia [Real estate: Renting rooms for students. The Italian situation]. Rentila. Retrieved from http://www.rentila.it/ blog/2017/10/31/il-punto-sullattualita-immobiliareottobre-2017

Giedion, S. (1929). Befreites Wohnen [Liberated dwelling]. Zurich: Orell Füssli.

Giedion, S. (1948). Mechanization takes command. A contribution to anonymous history. Oxford: Oxford University Press.

Ginzburg, M. (1934). Zhilischche [Dwelling]. Moscow: Gostroi-izdat.

Ginzburg, M. (2018). Dwelling: Five years' work on the problem of the habitation. Moscow: Fontanka Publishers.

Glendinning, M., \& Muthesius, S. (1994). Tower block. Modern public housing in England, Scotland, Wales, and Northern Ireland. London: Yale University Press.

Grassi, G. (Ed.). (1975). Das neue Frankfurt 1926-1931. Bari: Dedalo Libri.

Gubler, J. (2012). Nazionalismo e internazionalismo nell'architettura moderna in Svizzera [Modern architecture in Switzerland: Nazionalism and internationalism]. Mendrisio: Silvana.

Guerrand, R. H. (1981). Le origini della questione delle abitazioni in Francia (1850-1894) [The origins of the housing question in France (1850-1894)]. Rome: Officina Edizioni.

Heynen, H. (2005). Modernity and domesticity. Tensions 
and contradictions. London: Routledge.

Heynen, H., \& Baydar, G. (Eds.). (2005). Negotiating domesticity: Spatial productions of gender in modern architecture. London: Routledge.

Holl, S. (1997). Pamphlet architecture \#5: The alphabetical city. Princeton, NJ: Princeton Architectural Press.

Klein, A. (1928). Grundrissbildung und Raumgestaltung von Kleinwohnungen und neue Auswertungsmethoden [Plan design and spatial forms for the minimum dwelling and new methods of enquiry]. Berlin: Zentralblatt der Bauverwaltung.

Klein, A. (1934). Das Einfamilienhaus: Südtyp. Studien und Entwürfe mit grundsätzliche Betrachtungen [The family house: South type. Studies and projects with fundamental considerations]. Stuttgard: J. Hoffmann.

Klein, A. (1975). Lo studio delle piante e la progettazione degli spazi negli alloggi minimi. Scritti e progetti dal 1906 al 1957 [Plan studies and spatial design in minimum dwellings. Selected writings and projects, 1906 to 1957]. Milan: Mazzotta.

Lacaton, A., Vassal, J.-P., \& Druot, F. (2007). Plus. La vivienda colectiva. Territorio de excepción [Plus. Collective housing. Territory of exception]. Barcelona: Editorial Gustavo Gili.

Le Corbusier. (1996). Brevete sans Garantie du Gouvernement [Patents without government guarantee]. Lugano: Fidia Edizioni.

Liebscher, R. (2009). Wohnen für alle: Eine Kulturgeschichte des Plattenbaus [Housing for everyone: A cultural history of prefabricated housing constructions]. Berlin: Vergangenheitsverlag.

Macherez, F. (2015, June 16). Meet the Parisians. Paying a small fortune to live in shoebox apartments. Vice. Retrieved from https://www.vice.com/da/ article/exqpbm/the-inhabitants-maids-rooms-paris876?fbclid=IwAR2X1L-H77zG349Q-KkGqx9C8KfYr 467-dlwcfk2iExxJGBiF7TBHz1qy-w

Madden, D., \& Marcuse, P. (2016). In defense of housing. The politics of crisis. London: Verso.

Maier, C. S. (1970). Between Taylorism and technocracy: European ideologies and the vision of industrial productivity in the 1920s. Journal of Contemporary History, 5(2), 27-61.

Marescotti, F., \& Diotallevi, I. (1948). Il problema sociale, costruttivo ed economico dell'abitazione [The dwelling as social, constructive and economic problem]. Milan: Poligono.

McCamant, K., \& Durrett, C., (1988). Cohousing: A contemporary approach to housing ourselves. Berkeley, CA: Habitat Press.

Meehan, J. (2014). Reinventing real estate: The community land trust as a social invention in affordable housing. Journal of Applied Social Science, 8(2), 113-133.

Miller-Lane, B. (1968). Architecture and politics in Germany 1918-1945. Cambridge, MA: Harvard University Press.

Mumford, E. (2000). The CIAM discourse on urbanism,
1928-1960. Cambridge, MA: MIT Press.

Negri, A. (2012). Inventare il comune [Inventing the common]. Rome: DeriveApprodi.

Pattillo, M. (2013). Housing: Commodity versus right. Annual Review of Sociology, 39. https://doi.org/10. 1146/annurev-soc-071312-145611

Poppelreuter, T. (2011). Social individualism: Walter Gropius and his appropriation of Franz Müller-Lyer's idea of a new man. Journal of Design History, 24(1), 37-58.

Popupcity. (2016). Can co-living solve London's housing crisis? Popupcity. Retrieved from https://popupcity. net/can-co-living-solve-londons-housing-crisis

Roland, R. (2008). The ideology of home ownership. Homeowners society and the role of housing. New York, NY: Palgrave MacMillan.

Schütte-Lihotzky, M., \& Kinchin, J. (2011). Passages from "Why I Became an Architect". West 86th, 18(1), 86-96.

Stöhner, U. K. (1976). Untersuchung über den Beitrag Alexander Kleins zur Entwicklung und Bewertung von Grundrisse in Geschoßwohnungsbau [Research on Alexander Klein's contribution to the development and evaluation of floor plans in multi-storey flats]. Berlin: Berlin Institute of Technology.

Taylor, F. W. (1911). The principles of scientific management. New York, NY: Harper and Brothers Publisher.

Teige, K. (1932). Nejmenši byt [The minimum dwelling]. Prague: Václav Petr.

Teige, K. (1971). II problema degli alloggi dei ceti al minimo livello di vita [The problem of housing for the classes at the minimum level of life]. In C. Aymonino (Ed.), L'abitazione razionale. Atti dei congressi CIAM 1929-1930 [Rational dwelling. CIAM conference proceedings 1929-1930]. (pp. 208-215). Venice: Marsilio Editori.

Teige, K. (2002). The minimum dwelling. Cambridge, MA: MIT Press.

Thomas, Y. (2015). Il valore delle cose [The value of things]. Macerata: Quodlibet.

Ugo, V. (1986). Schema [Diagram]. In R. de Rubertis (Ed.), $X Y$ dimensioni del disegno $[\mathrm{XY}$, the dimensions of drawing] (pp. 21-32). Roma: Cedis Editrice.

Urban, F. (2012). Tower and slab. Histories of global mass housing. New York, NY: Routledge.

Vandkunsten Architects. (n.d.). Cohousing Jystrup Savvaerket. Vandkunsten. Retrieved from https:// vandkunsten.com/en/projects/co-living-jystrup

Vercellone, C. (2008). The new articulation of wages, rent and profit in cognitive capitalism. The art of rent. London: Queen Mary University School of Business and Management. Retrieved from https://halshs. archives-ouvertes.fr/halshs-00265584/document

Vey, J. (2016). Crisis protests in Germany, Occupy Wall Street, and Mietshäuser Syndikat: Antinomies of current Marxist- and anarchist-inspired movements and their convergence. Capital and Class, 40(1), 59-74. 


\section{About the Authors}

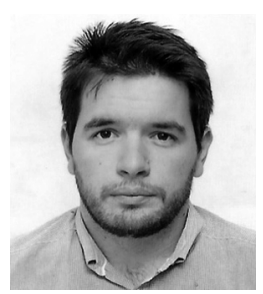

Marson Korbi is a PhD student, doctoral program "Architecture: Innovation and Heritage" (XXXII Cycle, Politecnico di Bari, Roma Tre). His main interests are related to housing, urban form and political problematics. He has written a series of essays on these themes, including: Loveless: A Short History of the Minimum Dwelling (2018, London, with Aureli and Tattara), Forms of Architecture and Resistance (2018, Tirana), New Forms of Living, the Metaphor of the City within (and against) the City (2018, Bari), New Forms of Dwelling: Living and Working Together within the Neoliberal City (2017, Tirana).

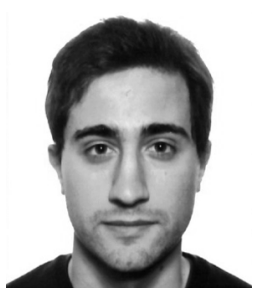

Andrea Migotto is an Architect and PhD student at the Faculty of Architecture of KU Leuven, Belgium. He studied at the Politecnico di Milano, Italy, and at the TU Delft, in the Netherlands, where he earned his master's degree in Architecture in 2015. He has worked as an architect in Brussels and in Melbourne. His research focuses on domestic space, specifically on the history, practices and architecture of social and affordable housing. 